\title{
Author Correction: Integrated genomic analyses of de novo pathways underlying atypical meningiomas
}

\author{
Akdes Serin Harmancl, Mark W. Youngblood, Victoria E. Clark, Süleyman Coşkun, Octavian Henegariu, \\ Daniel Duran, E. Zeynep Erson-Omay, Leon D. Kaulen, Tong Ihn Lee, Brian J. Abraham, Matthias Simon, \\ Boris Krischek, Marco Timmer, Roland Goldbrunner, S. Bülent Omay, Jacob Baranoski, Burçin Baran, \\ Geneive Carrión-Grant, Hanwen Bai, Ketu Mishra-Gorur, Johannes Schramm, Jennifer Moliterno, \\ Alexander O. Vortmeyer, Kaya Bilgüvar, Katsuhito Yasuno, Richard A. Young \& Murat Günel
}

Nature Communications 8:14433 doi: 10.1038/ncomms14433 (2017) Published online 14 Feb 2017; Updated 20 Apr 2018

In this Article, a subset of the H3K27ac ChIP-seq data (15 benign meningiomas and 2 dura samples (Sample IDs: MN-297, MN-288, MN-292, MN-163, MN-1037, MN-105, MN-201, MN-249, MN-191, MN-1066, MN-169, MN-291, MN-24, MN-79, MN-1044, CONTROL1, CONTROL2) was reported previously in a publication by the corresponding author ${ }^{1}$. These data were created by Dr. Justin Cotney in Dr. James Noonan's laboratory at Yale. The GEO database entry associated with this dataset has been updated to reflect this fact (GSE91372).

1. Clark et al., Genomic analysis of non-NF2 meningiomas reveals mutations in TRAF7, KLF4, AKT1, and SMO. Science 1, 1077-1080 (2013).

\footnotetext{
(c) Open Access This article is licensed under a Creative Commons Attribution 4.0 International License, which permits use, sharing, adaptation, distribution and reproduction in any medium or format, as long as you give appropriate credit to the original author(s) and the source, provide a link to the Creative Commons license, and indicate if changes were made. The images or other third party material in this article are included in the article's Creative Commons license, unless indicated otherwise in a credit line to the material. If material is not included in the article's Creative Commons license and your intended use is not permitted by statutory regulation or exceeds the permitted use, you will need to obtain permission directly from the copyright holder. To view a copy of this license, visit http://creativecommons.org/licenses/by/4.0/
}

(C) The Author(s) 2018 